\title{
包摂アーキテクチャ上のパラメータ探索を用いた 群ロボットによる適応的行動生成
}

\section{Generation of Adapting Behavior by Multi-Robot using Parameter Searching on Subsumption Architecture}

\author{
岡田 将吾東京工業大学大学院総合理工学研究科知能システム科学専攻 \\ Shogo Okada Department of Computatinal Intelligence and Systems Science, Tokyo Institute of Thechnology \\ okada99@isl.titech.ac.jp \\ 伊藤 芳子 \\ Yoshiko Ito \\ (同上) \\ ito@isl.titech.ac.jp \\ 長谷川 修 \\ 東京工業大学大学院理工学研究科像情報工学研究施設 \\ Imaging Science and Engineering Lab.,Tokyo Insititute of Thecnology \\ hasegawa@isl.titech.ac.jp
}

keywords: multi-robot system, subsumption architecture, machine learning, adaptation

\section{Summary}

In this research, we proposed multi-robot system that has robustness to the change of environments and has adaptability to the change of tasks and number of robots. To implement them, we use parameter learning on subsumption architecture. The subsumption architecture control robots' fundamental behaviors and robots move continuously in principle. The optimal value of the parameter and the number of robot that does the task in field are searched by learning. As the result,the robot's action on the task is improved (updated).Proposed system has functions to recognize the task and to generate the recordation memory.And then robots adapt to the change of tasks and the number of robots.In this paper, the function of proposed system is tested in simulation experiments.

\section{1. まえ がき}

一般に群ロボットは , 作業環境内の複数のロボットが 共通の目的をもって協調行動することにより，単独の口 ボットでは実現不可能なタスクを達成できる可能性があ る.また群ロボットは, タスクに対する柔軟性，耐故障 性，作業効率性の面で単独のロボットより優位性が見込 めるとされている[太田 01] .

しかし群ロボットにおいて, 個々のロボットの行動則 は人手によって設計可能であるが,「群」としての行動を 設計することは非常に難しい，乥こで，群ロボットに多 樣な協調行動を発現させ , 兴の中から「群」としての最 適な行動則を自律的に獲得 (学習) させる研究が近年盛ん に行われている .これらの研究では, 主として一定のタ スクを効率的に処理するための群ロボットの行動の最適 化に研究の主眼が置かれている.

これに対し本研究では，一定のタスクを効率的に処理 するだけでなく, タスクが変動したり，ロボットの台数 が変動する状況も考慮する．すなわち本研究では，

・ あるタスクを処理している最中に別のタスクが発生
する

・あるタスクを処理している最中に, 通信の不具合など の理由で協調行動を行えるロボットの台数が变化する といった状況下でも効率的な行動則を獲得できる群ロボッ 卜の実現を目指す．

本研究で提案する群ロボットでは, ロボットの基本的 な行動の制御に包摂アーキテクチャ[Brooks 86] を用い る.これにより個々のロボットは，原則としていかなる 状況にも停止することなく動き続ける．また本研究では 群ロボット全体を統御するリーダロボットを，タスクを 処理する度に決定する .これにより，いつどのロボット か做障したり追加されたりしても，対応可能としている．

ここでリーダロボットは, 作業フィールドに出るロボッ 卜の台数，および平衡状態のパラメータの適切な值を夕 スクに応じて探索する .これによりロボットのタスクに 対する行動が常に改善 (更新) される . またリーダロボッ 卜は, 後述する「タスクの認識」「記憶メモリの生成」を 行うことにより, タスクが変化する場合にも柔軟に対応 可能である .

以上の機能をシミュレーション実験により検証する.シ 
ミュレーション実験では，

（1）樣々なタスクに対し群ロボットとしての適切な行動 を獲得可能か

（2）パラメータの探索途中でタスクか変化する場合に 適応的にタスクを処理可能か

(3) パラメータの探索終了後および探索途中に通信卜 ラブルなどが発生した場合でも, 群ロボットとして の作業が破綻しないか

の 3 点を検証する .ここで (3) は, 提案メカニズムの実 ロボットへの搭載を視野にいれた上での課題である．実 ロボットは，通信ノイズや通信のタイムラグにより通信 不能となったり，故障する可能性がある．このような事 態が起きた場合にも，群ロボットとしての作業を破綻せ ず行えるかどうかをシミュレーション実験で検証する .

\section{2. 関 連 研 究}

群ロボットに関する研究は数多くなされているが, 光 れらの研究は 2 つに大別できる .

まず第一に, 特定のタスクに対する群ロボットの行動 則を予め設計する研究がある。例えば [Balch 98, Desai 01, Fredslund 02, 牧野 04]では, 樣々な障害物が存在す る環境下で群の挙動・隊列を制御する研究が行われてい る. [宮田 00] では , 複数台のロボットに周囲の環境に応 じて必要なタスクを動的に割り付ける手法が提案されて いる．また鳥や魚などの群れ集団の制御手法である boid モデル [Reynolds 87] も，群ロボットの挙動制御に用い られている . boid モデルでは, Separation(引き離し), Alignment(整列), Cohesion(結合)の 3 つのルールで群 の制御が行われる . boid モデルを用いて特定のタスクに 対する群の挙動・隊列を制御する研究例として [Miki 06] などがある .

第二に，群ロボットが協調行動を繰り返し行うこと により,最適な行動則を学習する研究がある，例えば [Kobayashi 03] では群の挙動・隊列における制御ルー ルが学習により獲得されている.この研究ではロボット 同士の最適な距離が Steady-State GA と呼ばれる遺伝 的アルゴリズムにより学習され，また障害物の回避行動 がQ-learningにより学習されている。. [则谷 04] では , 2 台の捕獲ロボットによる最適な協調挟撃行動が遺伝的ア ルゴリズムにより獲得されている . [Zhong 03, Kostiadis 99]では, サッカーフィールド上の各ロボットが連携動作 (協調行動) を繰り返すことによって，パスやシュートと いった，サッカーに関する協調行動が獲得されている．

前者の研究に対し，後者の学習を用いた群ロボットの 研究は, 通常学習に一定の時間を要する代わりに, 未知の タスクや難しいタスクに対しても適応的な行動則の獲得 が可能であるという利点がある (学習による適応性) . し かし [Kobayashi 03, Zhong 03, Kostiadis 99, 刈谷 04] などの学習により行動則を獲得する研究では, 特定の夕
スクの処理は可能であるが, 複数のタスクが混在する環 境下やロボットの台数か増減する環境下では機能しない．

これに対し，本研究では複数のタスクが混在する環境 下やロボットの台数が増減する環境下でも，学習により 適応的に行動することが可能なメカニズムを提案する .

\section{3. 群ロボットメカニズム}

\section{$3 \cdot 1$ 提案メカニズムの概要}

本研究では個々のロボットの基本的な挙動を包捸アー キテクチャにより制御する．包攝アーキテクチャは原則 としていかなる状況にも停止することなく動き続けるこ とが可能であるという利点を持つ．この機能を利用する ことで, 提案メカニズムはタスクか変化した場合や， ロ ボット間に通信卜ラブルなどが発生した場合にも破綻す ることなく動作を続けることが可能となる．

提案メカニズムでは作業フィールド内に生じる樣々な タスクを処理するために , 包摂アーキテクチャ上のパラ メータ探索を行い，群としての効率的な行動則を獲得す る. まず各ロボットの位置は作業フィールドの壁からの 反力 , 床からの摩擦力 , および他のロボットからの反力 により計算される．ここで，壁からの反力，および他の ロボットからの反カには弚れ光れ重みパラメータ (式 (2) の a,b) を掛ける .このパラメータを調節することで，口 ボットに作用する力は調節される .これらのパラメータ はタスク達成率に関する評価值を用いて最適化される またタスク処理に向かうロボットの台数もこの評価値を 用いることで最適化される.以上のパラメータ最適化に より群ロボットのタスクに対する処理効率の向上を目指 す . パラメータの最適化については $4 \cdot 4$ 節で述べる . 結 果的にパラメータ最適化の後，作業フィールド内で一定 台数のロボットがタスク発生に備え，予め適切な配置に 着くことができる

次に本研究では記憶メモリを生成することによって，経 験したことのあるタスクであれば探索状況を取り出して 探索を途中から再開し，経験したことのないタスクであ れば新しくメモリを作成して探索を始める．これにより， タスクか変化する状況にも迅速に対応し，より適切な行 動を取ることが可能となる. 記憶メモリの生成について は $4 \cdot 5 \cdot 5$ 節で述べる . また探索，記憶メモリの生成を行 うリーダロボットはタスク処理ごとに決定するため，い つどのロボットが故障した場合でも，群ロボットとして 停止することなく動作を続けることが可能である．

以上を総じて，提案メカニズムでは包攝アーキテクチャ にパラメータ探索の機能を追加することで, 群ロボット が複数のタスク処理を効率的に行うことが可能となる . さらに記憶メモリを導入することで, タスクの探索経過 を蓄積することが可能となり, 結果的に関連研究では達 成されていない, タスクか変化する環境下やロボットの 台数が増減する環境下でも，適応的に行動することが可 


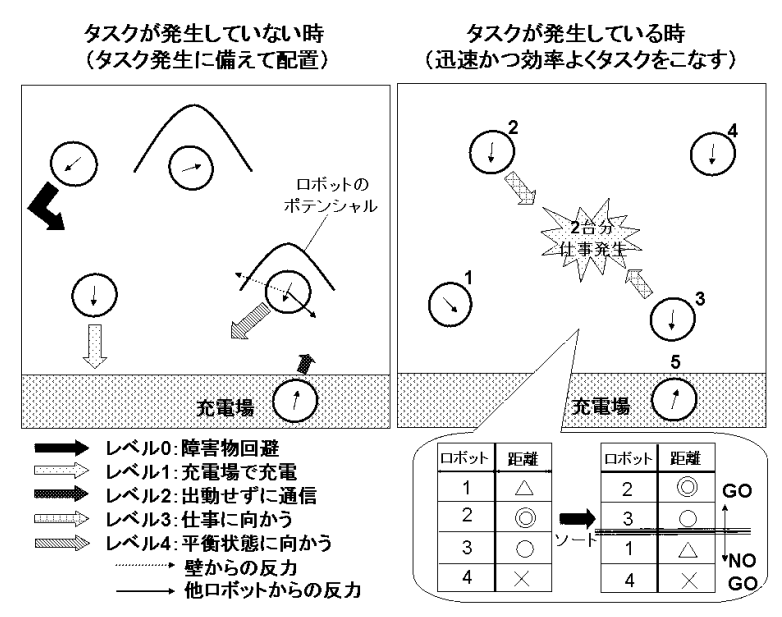

図 1 ロボットによる適応的行動生成

能となる

\section{$3 \cdot 2$ 問 題 設 定}

本研究では, 平面上の作業フィールドで処理すべきタ スクが発生する状況を想定する．この状況下で群ロボッ 卜が消費エネルギーや処理時間を節約して，光のタスク を効率的に処理できる適切なパラメータを探索可能かを 検証する．また処理すべきタスクが作業中に変化したり， 複数のロボットが作業中に通信不能になるという実環境 下で起き得る状況を設定し，これらの状況下においても 群ロボットとしての協調行動を続行可能かを検証する .

\section{$\S 1$ 作業フィールド :}

ロボットは $1000 \times 1000$ 単位の正方形の作業フィール ド内で活動する . 図 1 は, 群ロボットがタスクを処理する ための作業フィールドを表す .ここで図 1 の作業フィー ルドの灰色部をエネルギーの充電場とする . エネルギー 残量が一定值を下回ったロボットは，ここでエネルギー を補給する．

\section{$\S 2$ ロボット :}

ロボットは円柱形で, 8 個の赤外線センサと 2 個の車 輪を持つ. 各ロボットはセンサにより前後左右の物体の 存在か認識できる .

ロボットには以下のルールを設ける .

・ロボットはすべて均質であり，乥れ艺れが個別の口 ボット番号を持つ

・各ロボットはロボット間反力の計算のため周囲に一 定のポテンシャルを持つ

・移動距離や通信量に応じてエネルギーを消費する

・タスクの発生は少なくとも 1 台のロボットか認識可能

・ロボット同士は互いに通信可能

ここで, タスクの発生を 1 番最初に発見 (認識) した口 ボットから，順々に別のロボットにタスクの位置情報を伝 播させる $(4 \cdot 5 \cdot 6$ 節の伝播方法を用いる $)$. この操作によっ て全てのロボットはタスクと关の発生場所を認識する .

\section{$\S 3$ タスク :}

タスクとは発生する作業の一般的な名称と定義する．

タスクは作業フィールド内の充電場以外の場所に発生 する.ここでタスクの発生時間間隔は一定とする . また タスクはロボットに一定量のエネルギーを消費させる．

タスクにロボットか椡達すると, ロボットはタスクご とに設定された量 $E_{1}$ だけ，エネルギーを消費する．ま た各タスクでは, 処理に必要な最低限のロボット台数 (必 要台数 $(4 \cdot 3$ 節 $))$ か涽定される. タスクが発生すると光の 場所に指定された台数が集まり，設定されたエネルギー を消費する．よって例えばロボットの必要台数が 2 台で あるタスクを設定した場合, タスク発生場所に 2 台の口 ボットが集まり, 合計 $2 E_{1}$ のエネルギーを消費する .こ こで「ロボットの必要台数が 2 台であるタスク」など, 特 定のタスクの名称を表すときは Task と英字で表記する (5 章で定義).

$\S 4$ エネルギー

タスク処理で消費するエネルギー以外にも，移動距離， 通信量に応じてエネルギーは消費される．まずロボット は 2 個の車輪を回転させることで, フィールド上を移動 する. 各ロボットはこの車輪の回転数に応じてエネルギー を消費する .このエネルギーを移動エネルギー $E_{2}$ と定 義する . 次にロボットは情報を通信する間にエネルギー を消費する. 1 回の共有メモリ・記憶メモリへの書き込 み, および 1 回のロボット間の情報通信 (共有メモリの内 容をロボット同士で伝播する際の通信) により消費する エネルギーを $E_{3}$ と定義する．以上を加算して，一回の タスク処理で消費される総エネルギー $E_{a}$ を次式で表す．

$$
E_{a}=c_{1} \times E_{1}+\sum_{j \leq J} E_{2}(j)+\left(c_{2}+c_{3}\right) \times E_{3}(1)
$$

式 (1) で $c_{1}$ はタスク処理に必要なロボット台数,$j$ は口 ボットの番号， $J$ はタスク処理に向かうロボットの台数， $E_{2}(j)$ はロボット $j$ が移動で消費するエネルギー $($ 車輪 の回転数),$c_{2}$ (通信可能なロボットがタスクを処理する 間に通信した回数， $c_{3}$ は通信可能なロボットが共有メモ リ・記憶メモリへ書き込みを行った回数を乥れぞれ示す。

\section{4. 動作計画手法}

図 2 に個々のロボットのメカニズムを示す . 以下では 図 2 の各機能を順に説明する .

\section{$4 \cdot 1$ 包摂アーキテクチャ}

包摂アーキテクチャはシンプルな処理メカニズムを多 層に重ね，高レベルの層が低レベルの層を包捸する機構 である . 提案メカニズムでは包攝アーキテクチャに 5 層 のレベルを設定する (図 1 の左図下) . 


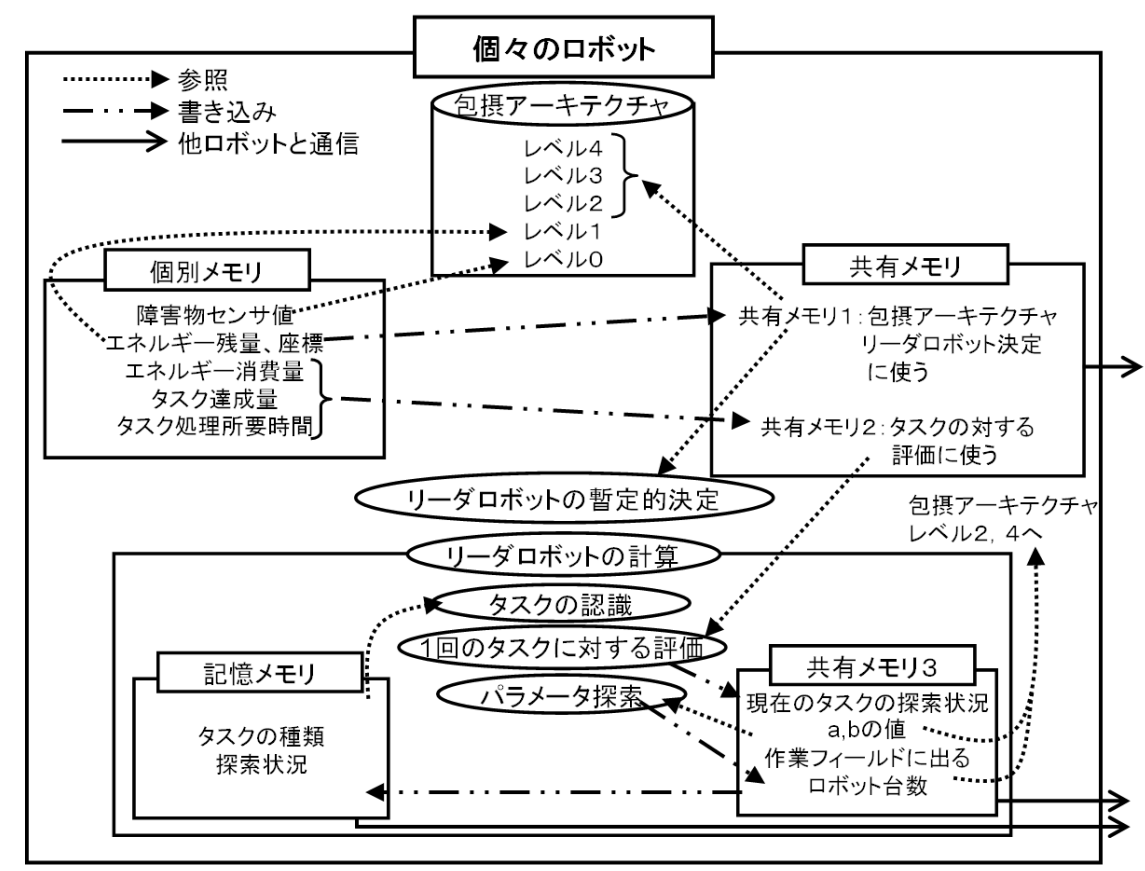

図 2 個々のロボットのメカニズム

・レベル 0 : 障害物回避および徘徊

障害物との距離が一定值以下なら回避行動をとる. 乥うでなければ徘䧃する.

・レベル 1 : 充電場で充電する エネルギー残量が一定値以下になると充電場に行っ て充電する .

・レベル 2 : 出動せずに通信のみを行う

作業フィールド内に存在するロボットがタスク処理 台数 (図 1 右の場合, 2 台)より多い場合で, かつ自 らが充電場にいる場合，出動せずに通信のみを行う． タスク処理台数とはパラメータ探索の結果として得 られる，タスク処理に向かうロボットの台数である.

・レベル 3 : タスクの処理

タスクが発生していればタスク発生場所までの距離 を計算し, 值が小さい順に必要な台数だけタスク処 理を行うロボットを決定する．

・レベル $4:$ 平衡状態に向かう

壁からの反力, 他のロボットからの反力・摩擦力を 受け, 力学的に平衡に達するように移動する .

以上により個々のロボットは, 原則としていかなる状況 でも停止することなく作業し続ける．以下ではレベル 0 ， レベル 2 , レベル 3 , レベル 4 についてさらに詳しく説 明する .

\section{$\S 1$ レベル 0:障害物回避および徘徊}

レベル 0 において, ロボットは他のロボットおよび障 害物を回避する.ここで通信可能なロボットはタスク発 生の通信を受けると, タスク処理に備える . 通信不可な ロボットは障害物を回避しながら徘䧃する。
$\S 2$ レベル 2:作業フィールドに出ずに通信のみを行う

レベル 2 では, タスク処理に備えて作業フィールドに 出るロボット台数を一定の台数 (タスク処理台数) にする. 図 2 の共有メモリ 1 に総ロボット台数分の出動判断の項 目を設ける．このレベルに達すると出動判断の項目が可 になっているロボット台数を数え, タスク処理台数より 多い場合は炎の項目を不可にして炎の場に留まり，通信 のみを行う.タスク処理台数より少ない場合は出動判断 の項目を可にし, 出動して上位のレベルに移行する .

ここでタスクの種類に応じて, タスク処理を行うロボッ トの台数は変化するので, パラメータ探索 (学習) によ り適切なタスク処理台数を求める.

\section{$\S 3$ レベル 3: タスクの処理}

レベル 3 ではタスクが発生している場合, タスクの処 理に向かうかどうかを判断する . 共有メモリ 1 にすべて

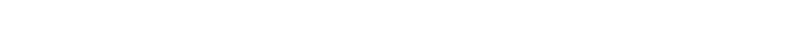
ロボットは自分の位置とタスク発生場所の位置までの距 離を計算する.タスク発生場所までの距離が小さい順に， タスク処理に必要な台数分ロボットが決定され, 決定さ れたロボットはタスク場所に向かう(図 1 の右図下).

\section{§ 4 レベル 4: 平衡状態に向かう}

作業フィールド上で発生するタスクを群ロボットが効 率的に処理するには, 各ロボットがタスク発生場所に対 して適切な配置をとる必要がある. 本研究では壁からの 反力とロボット同士の反力をロボットの制御手法に用い た.壁からの反力が大きく， ロボット同士の反力が小さけ ればロボットは中央に密集する．逆に壁からの反力が小 さく，ロボット同士の反力が大きければロボットは作業 フィールド全体に分散する .この 2 つの反に重み $(a, b)$ をかけ, 2 つの反力のバランスを調節することで, 各タ 
スクに対する適切な配置を獲得することが可能となる .

ここでロボット同士や壁からの反カがつりあった状態 を平衡状態と定義する . ロボット同士や壁からの反力は 以下で定義する.

・壁からの反力

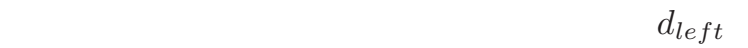
$d_{\text {right }}, d_{\text {up }}, d_{\text {down }}$ とすると, 壁から受ける反力の $x$ 成分 $f_{\text {wall }_{x}}, y$ 成分 $f_{\text {wall }_{y}}$ は

$$
\begin{aligned}
& f_{\text {wall }_{x}}=d_{\text {right }}-d_{\text {left }} \\
& f_{\text {wall }_{y}}=d_{\text {up }}-d_{\text {down }}
\end{aligned}
$$

・他のロボットからの反力

ロボット $i$ が他のロボット $j$ となす角を $\theta_{j}$, 距離を $d_{j}$ とすると, ロボット $i$ がロボット $j$ から受ける反 力の $x$ 成分 $f_{\text {robot }_{j x}}, y$ 成分 $f_{\text {robot }_{j y}}$ はガウス関数状 に近似して以下とする.

$$
\begin{aligned}
& f_{\text {robot }_{j x}}=A \times \exp \left(-d_{j}\right) \times \cos \theta_{j} \\
& f_{\text {robot }_{j y}}=A \times \exp \left(-d_{j}\right) \times \sin \theta_{j}
\end{aligned}
$$

ここで $A$ は実験的に定めた定数である．これを自身 以外のすべてのロボットについて求め, 合計したも のを他のロボットからの反力とする .

以上の反力に摩擦力 $f_{\text {react }}$ を加え, ロボット $i$ に働く力の $x$ 成分 $f_{i_{x}}, y$ 成分 $f_{i_{y}}$ を以下のように求める.

$f_{i_{(x, y)}}=a \times f_{\text {wall }_{(x, y)}}+b \times \sum_{j \neq i}^{j} f_{\text {robot }_{j(x, y)}}-f_{\text {react }_{(x, y)}}$

作業フィールド上の全てのロボットに対する $f_{i_{(x, y)}}=0$ となるところが平衡状態であり，ロボットは光の場所で 停止する．ここでパラメータ值 $a, b$ はタスクの種類や作 業フィールドに出るロボット台数に依存するため, $4 \cdot 4$ 節 のパラメータ探索 (最適化)により適切な值を求める.

\section{$4 \cdot 2$ リーダロボットの暫定的決定}

本研究では計算や行動の決定を行なうリーダロボット を初めから限定しない . タスクが発生するごとに図 2 の 共有メモリ 1 を参照して, ロボット番号が小さい順にエネ ルギー残量が一定値を上回っているロボット 1 台をリー ダロボットとし，弚のロボットが次から述べるタスクの 認識，パラメータ探索，記憶メモリの生成を行う。また リーダロボットか計算途中に故障すると他ロボットはリー ダロボットが故障したことを認識し，同樣の手順でリー ダロボットの再決定を行う．ここでタスク処理の過程で, リーダロボットの役割である共有メモリ 3 および記憶メ モリの更新が行われない場合にリーダロボットが故障し たと見なす。

\section{$4 \cdot 3$ タスクの認識}

タスクの変化に対応できるように, 現在どのようなタ スクが発生しているか (タスクの種類) をリーダロボッ
卜か認識する .ここでタスクの種類とは, タスク処理に 必要なロボットの最少台数とタスクの発生場所により定 義される。

タスクが発生するとリーダロボットはどこで, 最低何 台必要とされるタスクかを認識し, 記録をとって蓄積す る. 過去 10 回分のタスクの記録か蓄積されると, 10 回 分のタスク発生場所, およびタスク処理に必要なロボッ 卜の台数が一定であるかどうかを判定し，一定であれば 谷の発生場所，必要台数によるタスクであると決定する。 ただしタスク発生場所が毎回ランダムに変化する場合 $(5$ 章の実験における Task1〜3) には, 過去 10 回のタスク が全て別の場所で発生することになる．この場合にリー ダロボットはこのタスクをランダムな場所で起きるタス クであると認識する

ここで決定された必要台数は適切なパラメータを探索 する上での初期值となる.タスクが認識されると，弚れ が今までに経験したことのあるタスクか, 経験したこと のないタスクかの判断が行われる.タスクの認識が常に 行われることで, タスクが変化する場合にも柔軟に対応 することが可能となる .

\section{$4 \cdot 4$ パラメータ探索}

タスクを認識した後, ロボット全体のタスク処理を効率 化するためにパラメータ探索を行う .ここでタスク処理 を行うロボットの台数, および式 (2) におけるパラメータ $a, b($ 以下これら 3 つのパラメータの組をパラメータ状態 と呼ぶ）を探索し，適切なパラメータを決定する.タスク を認識できない間はパラメータ探索を行なわずに初期パ ラメータ状態 (ロボットの台数 $=$ 必要台数, $a=1, b=1)$ でタスクの処理を行う.

\section{$\S 1$ タスク処理に対する評価設定}

タスク処理に対するパラメータ状態の評価値は一回の タスクをこなすごとに式 (3) で計算する .

一回のタスク処理に対する評価值 $=$

$\left(\frac{\text { タスク達成量 }}{\text { 総エネルギー消費量 }}\right) \times \alpha+\left(\frac{\text { タスク達成量 } \times \gamma-\delta}{\text { タスク処理所要時間 }}\right) \times \beta(3)$

式 (3) のタスク達成量は式 (1) の右辺第一項と等価であ る.また式 (3) における総エネルギー消費量は $E_{a}($ 式 $(1))$ と等価である .

式 (3) の第一項はいかに平衡状態に向かう間のエネル ギー消費量を少なくしてタスク処理を行うか，つまり，い かに移動エネルギー (式 (1) の第二項) を消費せずにタス ク発生場所までたどり着けるかを評価している .

第二項はいかに所要時間を短くしてタスク処理を行う かを評価している.第二項の $\gamma, \delta$ は第一項の值との調整 のための実験的に定めた定数である. また $\alpha, \beta$ は 2 種 類の評価値にかかる重みパラメータで, 以下の条件を満 たす

$$
\left\{\begin{array}{l}
0 \leq \alpha, \beta \leq 1 \\
\alpha+\beta=1
\end{array}\right.
$$


事前に行った予備実験より，一つのパラメータ状態に よる評価值がタスクを 100 回こなすと安定することを検 証した。これより，一つのパラメータ状態に対してタス ク 100 回分の平均評価値を兴のパラメータ状態に対する 評価値とした .

\section{$\S 2$ パラメータの探索範囲}

タスクを認識した場合，弚れに応じたパラメータ探索 の探索範囲が決定される . 作業フィールドに出るロボッ 卜台数は (必要台数 $) \sim($ 必要台数 $)+2$ を探索範囲とし, 弚れ光れの台数において $a, b$ の探索範囲は $0 \sim 8$ の 2 次 元平面とする.このように探索範囲を決定したのは作業 フィールドに出るロボット台数がこれ以上増加すると, エ ネルギー効率の面から考えて評価に改善が見られなかっ たためである. また $a, b$ の值の探索範囲については，こ れ以上大きくするとロボットに㗢く反力がつりあわずに ロボットが平衡状態に達せず, ロボットの行動の評価に 改善が見られないことを予備実験により検証したことか ら決定した。

\section{$\S 3$ パラメータの探索手法}

パラメータ探索における, 初期探索地点を $(a, b)=(2,2)$, $(6,2),(4,4),(2,6),(6,6)$ と定義する .ここで, 初期探索 地点をこのように探索範囲に均等に散らばらせたのは局 所解に陥るのを極力防ぐためである .

探索の手順を図 3 に示す. 初期探索地点の評価値がす へて求まると, 弚の評価值の上位 3 つの探索地点を次の 探索の始点とし，兰れらの周囲の 8 点を探索する(例えば， $(2,2)$ から探索する場合 , 周りの 8 点 $(1,1),(1,2),(1,3),(2,1)$, $(2,3),(3,1),(3,2),(3,3)$ を探索する) . 次にこの 8 点の探索 地点の中で評価值が最大の地点を次の探索の始点とし， 同樣に光の点の周囲 8 点を探索して評価值が最大の地点 を探す . この操作を繰り返し始点の周囲の 8 点を探索し ても評価値に改善が見られなくなったら弚の始点を現在 のロボット台数における探索最終地点とし, 探索を終了 する .

次にロボット台数を一台増加して, 初期探索地点から 上記と同樣の探索を行う . 以上の探索をロボット台数 (( 必要台数 $)+2)$ まで行う. ロホホット台数 $(($ 必要台数 $)+2)$ までの探索を行った後に, すべての探索地点の中て評価 值が最大の地点を現在のタスクに対する探索最終地点と 決定する.この最終探索地点での, 作業フィールドに出 るロボット台数，および式 $(2)$ における $a, b$ の値を用い てタスク処理を行う。

本研究ではパラメータ探索の計算時間短縮を考慮して 探索するパラメータは整数值とした .

\section{$4.5 \times モ リ$ 生成}

上記の包摂アーキテクチャを実現するため，提案メカ ニズムでは [個別メモリ] と [共有メモリ 3 種類 $と$ [記憶 メモリ]を生成する．これらのメモリを生成することで， 提案する群ロボットはタスクが探索途中て変化した場合，

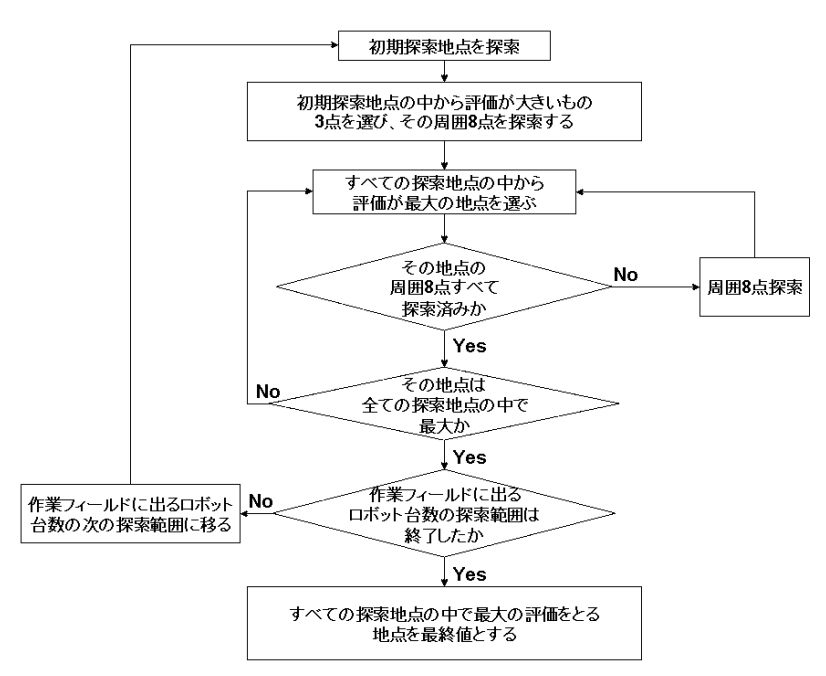

図 3 パラメータ探索の手順

およびロボットの台数か変化した場合にも破綻すること なく適切な行動をとることが可能となる。

\section{$\S 1$ 個別メモリ}

個別メモリには自身の障害物センサ值，エネルギー残 量, 座標値, タスク処理間のエネルギー消費量, タスク 達成量, タスク処理所要時間を書き込み, 他のロボット と通信は行わない

\section{$\S 2$ 共有メモリ 1}

個々のロボットは個別メモリ内のエネルギー残量と座 標を共有メモリ 1 に書き込み，自分が作業フィールドに 出るかどうかの出動判断を行い, 弚の判断した結果を書 き込む . これにより個々のロボットは他のすべてのロボッ トのエネルギー残量 , 座標 , 作業フィールドに出るかの判 断を知り，リーダロボットの暫定的決定に使用する . 個々 のロボットは個別メモリを更新する度に , 共有メモリ 1 に弚の結果を書き込む．

\section{$\S 3$ 共有メモリ 2}

共有メモリ 2 には個々のロボットが個別メモリからエ ネルギーの消費量, タスク達成量, タスク処理所要時間 を書き込み，リーダロボットがタスクに対する評価を行 う際に使用する . タスクの処理か終了するごとに個別メ モリから上記の情報が共有メモリ 2 に書き込まれる .

\section{$\S 4$ 共有メモリ 3}

リーダロボットは現在のタスクの探索状況とパラメー 夕值 , 作業フィールドに出るロボット台数を共有メモリ 3 に書き込む．タスクの探索状況とパラメータ值はリーダ ロボットがパラメータ探索をする際に使用し，パラメー 夕值と作業フィールドに出るロボット台数は個々のロボッ トが包摂アーキテクチャで動作する際のレベル 2,4 で参 照する。

\section{$\S 5$ 記憶メモリ}

タスクに対するパラメータ探索をしている最中やパラ メータ探索が終了した後に, 課されるタスクが変化した 
場合 ， タスクへの迅速な対応は困難となる . 上記の状況 に対応するために, タスク処理経験を記憶メモリに蓄積 する .

記憶メモリにはタスクの種類と，探索の進捗状況を組 にして書き込む．ここでタスクの種類とは， $4 \cdot 3$ 節で述 ベた, タスク処理に必要なロボットの最少台数と発生場 所の二項目である .

また探索の進捗状況（図 2 における記憶メモリの中の 探索状況）とは，現在の時点でのパラメータ状態の探索 結果 $(\mathrm{a}, \mathrm{b}$, ロボット台数) を指す .

リーダロボットか現在のタスクと認識したタスクの種 類を比べてタスクの種類が変化したと認識すると, 記憶 メモリを参照して今までに経験したことのあるタスクか どうかを判断する．今までに経験したことのないタスク であれば，新しく記憶メモリの形成を行い，初めからパ ラメータ探索を進める，一度経験したことのあるタスク ならば, 記憶メモリの中から同じ種類のタスクを探し，探 索の進捗状況を取り出して続きから探索を再開する (図 4 における工程 (7) から (10)) . 探索後にパラメータ状態 (a,b, ロボット台数) と，㚇のパラメータ状態に対する評 価は記憶メモリに書き込まれる．個々のロボットの，メ モリ $(4 \cdot 5 \cdot 1$ 節〜 $4 \cdot 5 \cdot 5$ 節 $)$ の更新手順および処理手順を 図 4 に示す.

\section{$\S 6$ メモリの共有方法}

個別メモリ以外の共有メモリおよひ記憶メモリ $(4 \cdot 5 \cdot 2$ 節〜 $4 \cdot 5 \cdot 5$ 節) は，各ロボットで共有される . 本節ではこ れらのメモリの内容および情報を，ロボット同士の間で 共有する (通信する) 手法について説明する．ここで各口 ボットには番号が付けられており，基本的にはこの番号 順に通信を行う . 各ロボットは総ロボット数の情報を与 えられているものとする . 以下では, 総ロボット数が 5 台の場合を例として説明する. 以下の説明で $1 \rightarrow 2$ とい う表記は 1 番のロボットが 2 番のロボットに情報を伝播 することを意味する．

リーダロボットの選出

一定量以上のエネルギ残量を有するロボット (共有メ モリ 2)の中で 1 番タスク発生場所に近いロボット (共有 メモリ 1) がリーダロボットとなる . 1 番のロボットから $(1)(1 \rightarrow 2 \rightarrow 3 \rightarrow 4 \rightarrow 5)$ の順に共有メモリ 1 と共有メ モリ 2 の書き込みを行う . このメモリ伝播 (1) をもう一 度繰り返すことで, リーダロボットとなるロボットの番 号を全ロボットか認識する . 共有メモリおよび記憶メモ リの更新

共有メモリ 1 〜 および記憶メモリが更新された時， リーダロボットが番号の 1 番若いロボットにメモリの内 容を通信する . 若い番号のロボットから , 番号の若い順 にメモリの内容を伝播させる.例えばリーダロボットが 3 番の場合 , 伝播する順番は $(2)(3 \rightarrow 1 \rightarrow 2 \rightarrow 3 \rightarrow 4 \rightarrow$ $5 \rightarrow 3)$ となる . これよりリーダロボットに通信か帰って 来た時点で, メモリが全ロボットで共有された状態とな

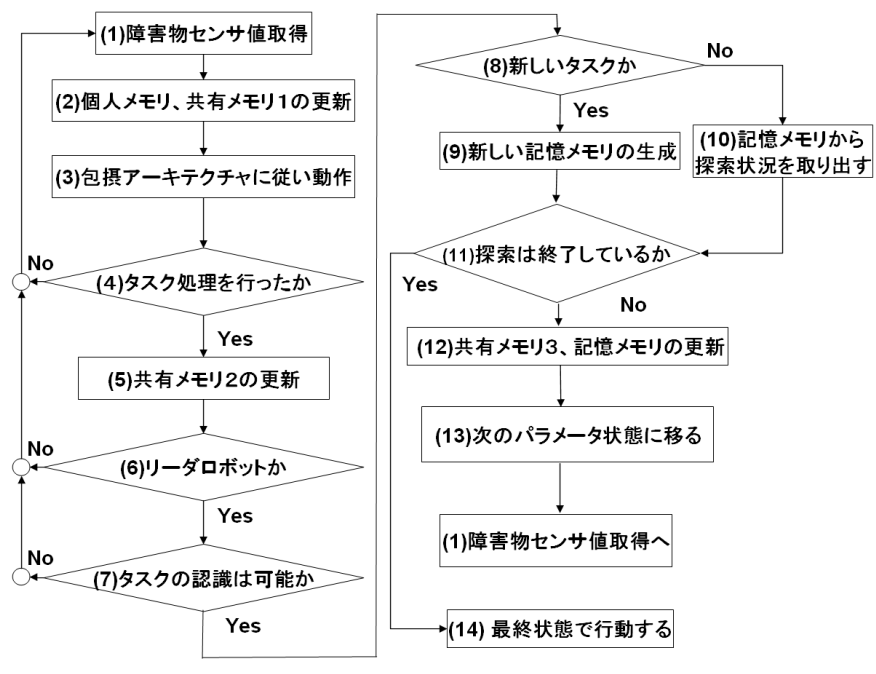

図 4 個々のロボットの処理手順 (タスクに対してパラメータを探 索する過程で, (1) から (13) を繰り返し行う . パラメータ 探索が終了すると (14) の分岐に移り, 兴のパラメータ状態 で群ロボットは動き続ける、リーダロボットに選ばれた一体 のロボットは (7) 以降の作業を行う . (7) では過去 10 回の タスクが一定であった場合，(8)の分岐に移る .)

る

ロボットの通信障害への対策

ロボットが故障した場合，メモリの情報伝播が滞る . この問題を回避するため，情報の伝播が平常に行われた ら，情報の受け手側から送り手側に受領信号を送る. 受 領信号が一定時間 $T$ を超えても送られない場合，送り手 側は受け手側が故障しているとみなし，番号を順次飛ば して通信する．ここで情報の送り先が見つからない場合， 最大で総ロボット数まで飛ばして通信を行う.上記のメ モリ伝播 (2) で例えば 4 番が故障した場合 , 伝播する順 番は $(3)(3 \rightarrow 1 \rightarrow 2 \rightarrow 3 \rightarrow 5 \rightarrow 3)$ となる. 伝播した口 ボットの数を数えておくことで, リーダロボットに通信 が帰ってきた時, リーダロボットは現在何台のロボット が正常に機能するかを把握する．

ここでタスク処理の途中に記憶メモリおよび共有メモ リ 3 の情報が 3 番のリーダロボットから伝播されなかっ た場合，リーダロボットが故障しているとみなし再びリー ダロボットの選出を行う.

以上の方法によって, 各ロボットは更新されたメモリ および炎の他の情報を共有する .

\section{5. シミュレーション実験の結果と考察}

以上のアルゴリズムの有用性を検証するために，[Khepera Simulator version 2.0] によりシミュレーション実験 を行った . 充電場 , 作業フィールド全てを含むフィールド 上の総ロボット数は 5 台, タスクは表 1 に示す 9 種類を設 定した .ここで，ある特定のタスクの名称を Task(表 1) と表記する . 例えば「Task2」は , フィールド上の Random な場所に発生し, ロボットを最低 2 台要するタスク 
$(3 \cdot 2 \cdot 3$ 節) を指す . 各 Task の発生場所は, 1 箇所の場合 $(500,410)$ の位置に，2 箇所の場合 $(200,200)(800,200)$ の位置に発生することとした .

$5 \cdot 1$ 節では, 9 種類の Task に対して適切な行動則 (パ ラメータ状態) を獲得可能かどうかを検証する $.5 \cdot 2$ 節 , $5 \cdot 3$ 節では, タスク処理環境の変化に対する群ロボット の適応性について検証する .

具体的に, $5 \cdot 2$ 節ではタスク処理の途中で Task が変 化する場合のシミュレーションを行う. $5 \cdot 3$ 節では, タ スク処理の途中で数台のロボットが通信不可となり，協 調行動を行えるロボットの台数が減少する場合のシミュ レーションを行う．

\section{$5 \cdot 1$ 各タスクに対するパラメータ状態の探索}

タスクの種類は一定で式 (3) における $\alpha, \beta$ の值を $(1.0,0.0),(0.0,1.0),(0.5,0.5)$ の 3 種類に設定して実験を 行った.

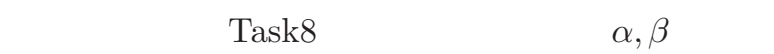
対する評価値の変化を図 5 に示す.横軸は群ロボットの 動作経過時間を示し，時間間隔は 1pas とした . 1 pas は 全ロボットが同時に車輪を回転させて，1 つの動作 (例， 左を向く，一歩前に進む）を行う時間を示す．また縦軸は 評価値を示す．図中の緑線は探索終了線を示し，青線は 探索する作業フィールドに出るロボットの台数が 1 台増 加される時間を示す.すなわち，ここでは「Task8の必要 台数」からパラメータ a,b の探索・評価をはじめ「TTask8 の必要台数 +2 台」になるまでパラメータ a,b の探索・ 評価を行う.

いずれの評価においても, 緑線以降は探索が終了して いるので光れまでの中で一番良い評価值を出力するパラ メータ (ロボット台数および $\mathrm{a}, \mathrm{b})$ で行動を行っているこ とがわかる .

$(\alpha, \beta)=(1.0,0.0)$ (図 5 左上) の場合 , 作業フィールド に出るロボット台数か増えると弚れに伴いエネルギー消 費量が増加してしまうため, 増加と共に評価值は下がる .

$(\alpha, \beta)=(0.0,1.0)$ (図 5 右上)の場合 , 作業フィールド に出るロボット台数か増えると評価か改善されている .こ

表 1 タスクの種類

\begin{tabular}{|c|c|c|}
\hline タスクの種類 & 必要台数 & 発生場所 \\
\hline Task1 & 1 & Random \\
\hline Task2 & 2 & Random \\
\hline Task3 & 3 & Random \\
\hline \hline Task4 & 1 & 1 箇所 \\
\hline Task5 & 2 & 1 箇所 \\
\hline Task6 & 3 & 1 箇所 \\
\hline \hline Task7 & 1 & 2 箇所 \\
\hline Task8 & 2 & 2 箇所 \\
\hline Task9 & 3 & 2 箇所 \\
\hline
\end{tabular}
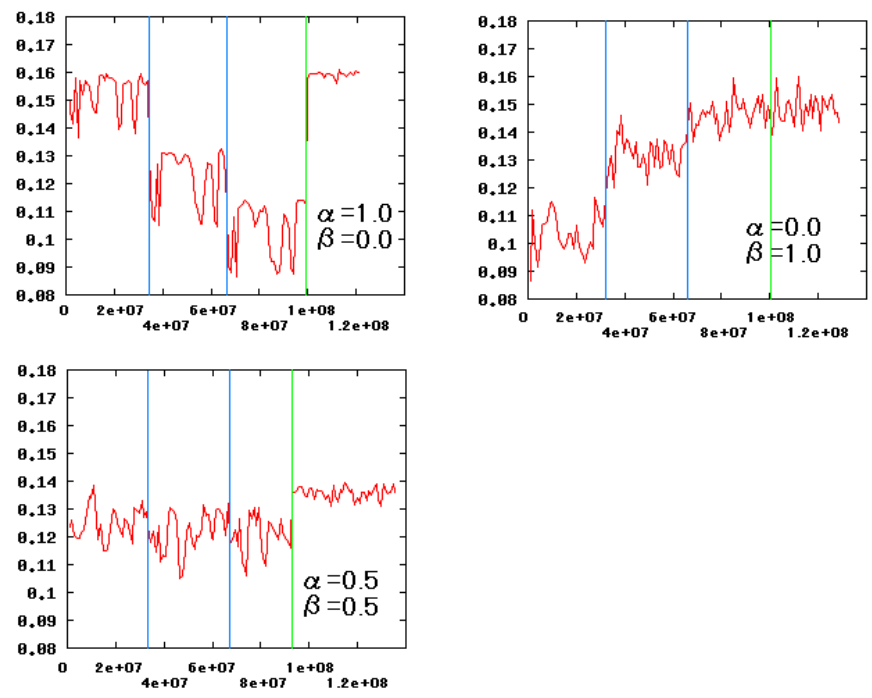

図 5 Task8 における評価値の遷移 (3つの図において, 横軸は動 作経過時間 (単位：pas) 縦軸は評価值 (式 (3)) を示す. 3 つ の図より探索が終了すると (図中の緑線)，群ロボットは一 番良い評価値を与えるパラメータ状態で行動していることが わかる . )

れは作業フィールドに存在するロボット台数が多いほど 迅速にタスク発生場所まで到達できるためである．2 種 類の評価を考慮に入れた $(\alpha, \beta)=(0.5,0.5)$ (图 5 左下)で はフィールドに出るロボット台数による評価値の変化は ほとんどない . 上記の傾向はタスクの発生場所がランダ ムな場合 (Task1〜3) と 2 箇所の場合 (Task7〜9) にも共 通して起こった。

次の例として , タスクの発生場所が 1 箇所である Task6 における弚れ光れの $\alpha, \beta$ の組に対する評価值の変化を図 6 に示す.ここでも，緑線以降は評価値の中で一番良い 評価值を出力するパラメータ (ロボット台数および $\mathrm{a}, \mathrm{b}$ ) で行動を行っていることがわかる .

$(\alpha, \beta)=(1.0,0.0)$ (図 6 左上) の場合はタスク発生場所 が 1 箇所のときもランダム, 2 箇所と同樣に作業フィー ルドに出るロボット台数が多くなるにつれて評価值が下 がっている.

$(\alpha, \beta)=(0.0,1.0)$ (図 6 右上) の場合は作業フィールド に出るロボット台数が増えると評価が改善されるとは限 らない .これはロボット台数か増えるとかえって他ロボッ 卜の行動を妨害してしまう可能性があるからである .こ のような傾向はタスクの必要台数に限らずタスクの発生 場所が 1 箇所の場合 (Task4 6) に共通して起こる .

$(\alpha, \beta)=(0.5,0.5)$ (図6 左下) の場合も， $(\alpha, \beta)=(1.0,0.0)$ と同樣に作業フィールドに出るロボット台数が多くなる につれて評価值か下がっている .

パラメータ探索の結果，群ロボットはタスクを効率よ くこなす行動則を発見的に獲得した。ここで探索後の最 適なパラメータを獲得した群ロボットが，作業フィール ドでどのような行動を取るかを詳しく考察する . 表 2 に 

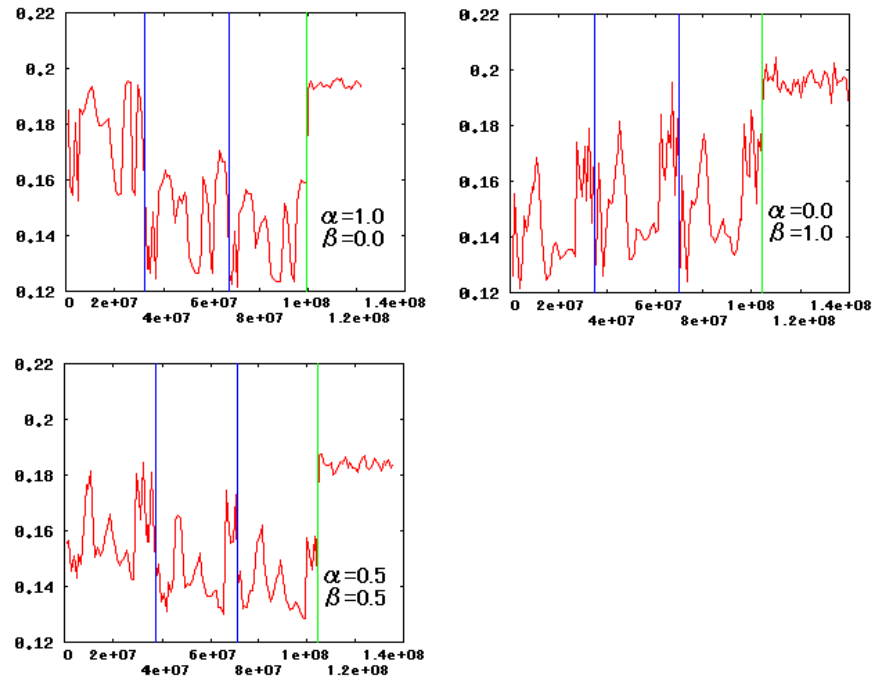

図 6 Task6 における評価値の遷移 (3つの図において, 横軸は動 作経過時間 (単位：pas) 縦軸は評価值 (式 (3)) を示す. 图 5 と同樣に，探索が終了すると (図中の緑線) 群ロボットは一 番良い評価值を与えるパラメータ状態で行動していることが わかる．）

表 2 各 Task に対する探索後のパラメータ (台数は, (必要台数 $\rightarrow$ 適切な台数) として表記される .)

\begin{tabular}{|c||c|c||c|c||c|c|}
\hline \multicolumn{1}{|c||}{} & \multicolumn{2}{c||}{$\begin{array}{c}(\alpha, \beta)= \\
(1.0,0.0)\end{array}$} & \multicolumn{2}{c||}{$\begin{array}{c}(\alpha, \beta)= \\
(0.0,1.0)\end{array}$} & \multicolumn{2}{c|}{$\begin{array}{c}(\alpha, \beta)= \\
(0.5,0.5)\end{array}$} \\
\cline { 2 - 7 } & 台数 & $(a, b)$ & 台数 & $(a, b)$ & 台数 & $(a, b)$ \\
\hline \hline Task1 & $1 \rightarrow 1$ & $(1,7)$ & $1 \rightarrow 3$ & $(5,5)$ & $1 \rightarrow 1$ & $(3,3)$ \\
\hline Task2 & $2 \rightarrow 2$ & $(0,1)$ & $2 \rightarrow 4$ & $(7,1)$ & $2 \rightarrow 2$ & $(5,2)$ \\
\hline Task3 & $3 \rightarrow 3$ & $(1,0)$ & $3 \rightarrow 5$ & $(6,1)$ & $3 \rightarrow 3$ & $(6,1)$ \\
\hline \hline Task4 & $1 \rightarrow 1$ & $(5,2)$ & $1 \rightarrow 2$ & $(7,3)$ & $1 \rightarrow 1$ & $(6,2)$ \\
\hline Task5 & $2 \rightarrow 2$ & $(3,1)$ & $2 \rightarrow 3$ & $(8,1)$ & $2 \rightarrow 2$ & $(8,1)$ \\
\hline Task6 & $3 \rightarrow 3$ & $(6,1)$ & $3 \rightarrow 4$ & $(5,0)$ & $3 \rightarrow 3$ & $(8,1)$ \\
\hline \hline Task7 & $1 \rightarrow 1$ & $(2,4)$ & $1 \rightarrow 3$ & $(2,3)$ & $1 \rightarrow 1$ & $(4,5)$ \\
\hline Task8 & $2 \rightarrow 2$ & $(1,1)$ & $2 \rightarrow 4$ & $(6,7)$ & $2 \rightarrow 2$ & $(7,1)$ \\
\hline Task9 & $3 \rightarrow 3$ & $(0,0)$ & $3 \rightarrow 5$ & $(7,3)$ & $3 \rightarrow 3$ & $(6,1)$ \\
\hline
\end{tabular}

は各 Task に対して探索を行った後に，得られた最適な パラメータを示す.表 2 の台数は , (初期に設定した必要 台数 $\rightarrow$ 探索後の適切な台数) として表記される.表 2 に おいて , $a$ の值が大きい場合，壁からの反力が強いため 群ロボットは中央付近に集まった . bの值が大きい場合， ロボット同士の反力か強いためロボット同士の距離が大 きくなり，群ロボット全体としてはフィールド上に分散 した配置をとった .

\section{$\S 1$ Task1,Task2,Task3 について}

Task1〜Task3 は作業フィールド内のランダムな位置 にタスクが発生する場合である。

式 (3) において $(\alpha, \beta)=(1.0,0.0)$ のとき，ロボットは 消費エネルギー量が少なくなるように行動する．タスク がランダムに発生する場合はタスク処理の必要台数にか かわらず, 作業フィールドに出るロボット台数は必要最 低限で $a, b$ の值は $0 \sim 1$ の小さな值になる (作業フィー
ルドに出るロボット台数が 1 台の場合は他ロボットから の反力は受けないので, $b$ の值については無視する）.つ まりどこでタスクが発生するかわからない状況では, エ ネルギー消費を軽減するために, 群ロボットはタスクに 備えて配置に着くという行動でなく，兴の場で動かない という行動を選択した。

$(\alpha, \beta)=(0.0,1.0)$ のとき，ロボットは迅速にタスク発 生場所までたどり着けるように行動する.ランダムにタ スクが発生する場合, 必要台数が 1 台〜3 台のタスク (Task1 3) の間で結果が変化した . 必要台数が 1 台の 場合は作業フィールドに出るロボット台数は探索範囲内 で最大值 3 となり， $a, b$ の值は共に探索範囲内の中程度の 值になり，ロボットは作業フィールド内にロボット同士 の距離をある程度に保ちながら分散した .これによりタ スクが発生したときに, ロボット 1 台ずつに作業フィー ルドの領域が割り当てられるため, 迅速にタスク発生場 所に向かうことが可能となる. ロボットの必要台数が 2 台, 3 台のタスクの場合, ロボットの振る舞いは大きく 変わった。作業フィールドに出るロボット台数は探索範

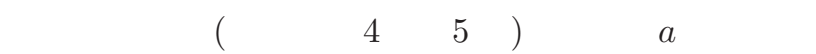
きく, $b$ の值は小さくなり, ロボットは作業フィールドの 中心付近に集まるようになった

総じて $(\alpha, \beta)=(0.0,1.0)$ の場合, 提案する群ロボット はタスク処理所要時間の短縮を考慮し, タスク処理に必要 な台数全てのロボットを作業に当たらせた . またTask2, Task3 では, 迅速に必要とされるロボットを集合させる ために , 作業フィールドの中心付近に全てのロボットを 待機させる選択を取った 。

図 7 に $(\alpha, \beta)=(0.0,1.0)$ における適切なパラメータ 状態で行動するロボットの樣子を示す．

次に $(\alpha, \beta)=(0.5,0.5)$ の場合，ロボットは 2 種類の 評価 (エネルギー効率と時間効率) を考慮して行動する ことになる．適切なロボット台数は，作業フィールド内 に出るロボット台数の増加に伴うエネルギー消費量の増 加の影響が大きいために， $(\alpha, \beta)=(1.0,0.0)$ の場合と同 樣の結果となった .一方 $(a, b)$ の值は, Task2,Task3 の とき $(\alpha, \beta)=(0.0,1.0)$ の場合に近い値が得られた .し かし Task1 のとき $a$ の值は , $(\alpha, \beta)=(0.0,1.0)$ の場合 と $(\alpha, \beta)=(1.0,0.0)$ の場合の中間値をとった . $(\alpha, \beta)=$ $(0.5,0.5)$ の場合に, 最適パラメータ状態で行動するロ ボットの樣子を図 8 に示す.

以上をまとめると，Task1,Task2,Task3 に対して最適 パラメータの探索を行った結果，提案メカニズムは, エネ ルギー効率に対する評価を重んじた場合 $((\alpha, \beta)=(1.0,0.0))$ ， タスク処理の時間効率に対する評価を重んじた場合 $((\alpha, \beta)=$ $(0.0,1.0))$ ，および弚れら両方を均等に重んじた場合 $((\alpha, \beta)$

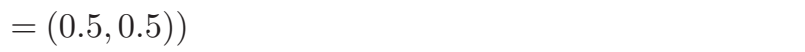
るパラメータを探索可能であった . 


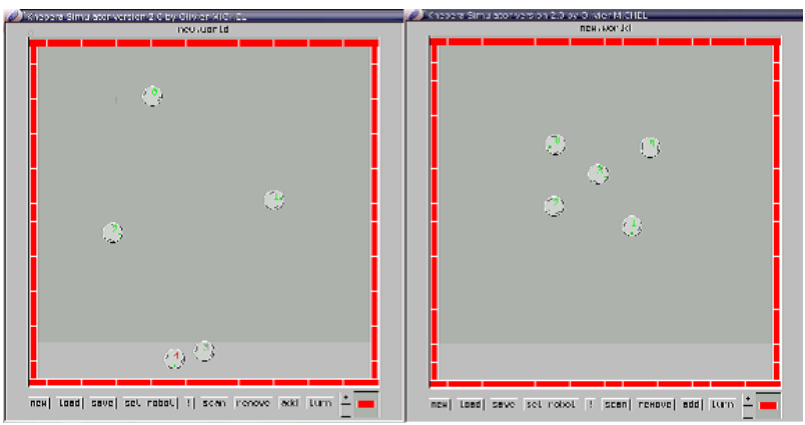

図 $7(\alpha, \beta)=(0.0,1.0)$ における Task1 と Task3 の適切なパラ メータ状態よる群ロボットの行動 (左 : 3 台が分散配置 右 : 5 台が中央付近に集結)

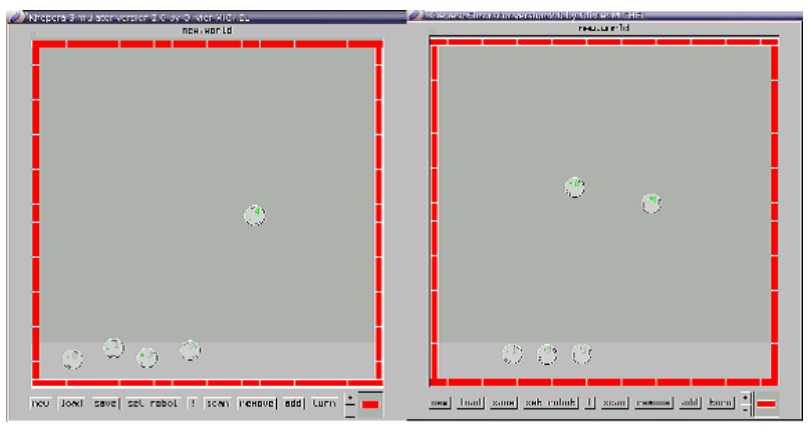

図 $8(\alpha, \beta)=(0.5,0.5)$ における Task1 と Task2 の最適パラメー 多状態によるロボットの行動 (左: 1 台が中央付近に配置 右: 2 台が中央付近に配置)

\section{$\S 2$ Task4,Task5,Task6 について}

Task4〜6 は作業フィールド内の 1 箇所 $(500,410)$ (作 業フィールドの中央) でタスクが発生する場合である .

$(\alpha, \beta)=(1.0,0.0)$ の場合 , タスク処理に必要な台数に 関係なく作業フィールドに出るロボット台数は必要最低 限で , $a$ の值は大きく,$b$ の値は小さくなった .すなわち タスクの発生場所近くに集まるという行動を選択した .

$(\alpha, \beta)=(0.0,1.0)$ の場合 , 作業フィールドに出るロボッ 卜台数は (タスク処理に必要なロボット台数) +1 にな り, $a$ の値は大きく,$b$ の值は小さくなった . すなわちこ の場合もロボットは作業フィールドのタスクの発生場所 付近に集まるようになった。よって， $(\alpha, \beta)=(1.0,0.0)$ の場合に比べ, タスク処理にかかるロボットの台数を増 加させる戦略がとられた .

$(\alpha, \beta)=(0.5,0.5)$ の場合，作業フィールドに出るロ ボット台数は $(\alpha, \beta)=(1.0,0.0)$ の場合と同樣であるが， $a, b$ の値は $(\alpha, \beta)=(0.0,1.0)$ の場合により近くなった . $(\alpha, \beta)=(0.5,0.5)$ の場合には，常に作業発生場所付近 にロボットが配置されるという挙動が得られた . 総じて Task4,Task5,Task6で , a の值が大きく b の值が小さい 場合にロボットがタスク発生場所付近に集まるのは，タ スク発生場所がフィールド中央 $(500,410)$ のためである . これよりタスクの位置に応じたパラメータ探索が可能で あることが示された .

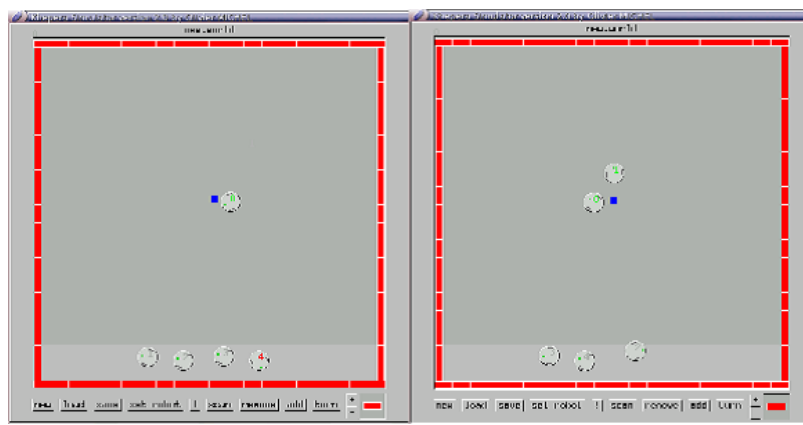

図 $9(\alpha, \beta)=(0.5,0.5)$ における Task4 と Task5 の最適パラメー タ状態によるロボットの行動 (左 : 1 台がタスク発生場所付 近に配置 右 : 2 台がタスク発生場所付近に配置)

ここで $(\alpha, \beta)=(0.5,0.5)$ において最適パラメータ状態 で行動するロボットを図 9 に示す. 図中の青点はタスク の発生場所 $(500,410)$ の位置を示す . また左図は Task4 の場合，右図は Task5 の場合を示す .

\section{$\S 3$ Task7,Task8,Task9 について}

Task7〜 9 は作業フィールドの $(200,200),(800,200)$ の 2 箇所にタスクが発生する場合である

$(\alpha, \beta)=(1.0,0.0)$ の場合，タスク処理に必要な台数に 関係なく，作業フィールドに出るロボット台数は必要最 低限で $a, b$ の值は小さくなった .これはロボットはタス ク処理に行く以外あまり動かないことを意味する．すな わち Task1 3の $(\alpha, \beta)=(1.0,0.0)$ の場合と同樣に，工 ネルギー消費を軽減するため, 弚の場に留まるという行 動を取ったと考えられる

$(\alpha, \beta)=(0.0,1.0)$ の場合， タスク処理に必要な台数が 何台でも，作業フィールドに出るロボット台数は探索範 囲内で最大になった .たとえばタスク処理に必要な台数 が 1 台のタスク (Task7) の場合, 1 台ずつロボットがタ スク発生場所に配置可能なように $a, b$ の值か調整された .

タスク処理に必要なロボット台数が 2 台, 3 台になると $a, b$ の值は両方とも大きくなり, ロボットは反力の平衡 がとれずに振動しながら作業フィールド内で分散された . フィールドに出るロボット台数がタスク処理に必要な台 数より多い場合はある程度分散した方が迅速にタスク発 生場所に到着が可能であり, 作業効率も向上する .ここ で $(\alpha, \beta)=(0.0,1.0)$ における最適パラメータ状態による ロボットの行動を図 10 に示す . 図中の青点はタスクの発 生場所 $(200,200),(800,200)$ の位置を示す . また左図は Task7 の場合，右図は Task8 の場合を示す . $(\alpha, \beta)=$ $(0.5,0.5)$ の場合，作業フィールドに出るロボット台数は $(\alpha, \beta)=(1.0,0.0)$ のときと同じく必要最低限で， $a$ の值 は大きく $b$ の值は小さくなり, ロボットはフィールドの 中心付近に集まった .これは $\beta$ の値による影響であり， 作業フィールドにでるロボット台数が必要最低限の場合 はすべてのロボットが中央付近にいる方がタスク発生場 所に迅速に到着できるからである . 


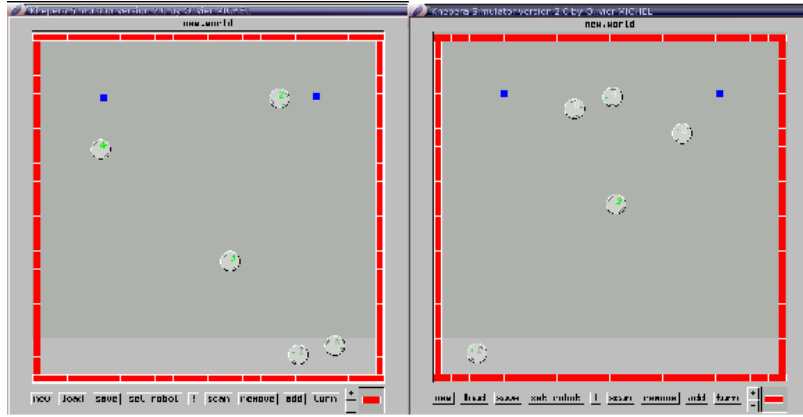

図 $10(\alpha, \beta)=(0.0,1.0)$ における Task7 と Task8 の最適パラ メータ状態によるロボットの行動 (左 : 3 台中 2 台がタス ク発生場所付近に配置 右 : 4 台が分散配置)

\section{$5 \cdot 2$ タスクの種類が変化する場合の探索}

この節では，あるタスクに対する作業の途中 (最適パ ラメータを探索している最中) に, タスクの種類が変化 した (別のタスクが発生した) 場合でも探索が有効に進む ことをシミュレーションにより検証する .

本実験では Task3,Task6,Task7(表1) の計 3 種類の夕 スクを設定した .これらのタスクを Task6,1000 回 $\rightarrow$ Task2,3000 回 $\rightarrow$ Task7,4000 回と繰り返し発生させた . またこの実験での評価値の重みは $(\alpha, \beta)=(0.5,0.5)$ と した .この実験では, 変化しながら課される複数のタス クに対し，群ロボットがいかに最適な行動を探索可能か を検証する。

上記の実験結果を图 11 に示す. 图 11 は上記のタス クを処理する過程での，探索率および評価值の変化を表 す.図 11 において緑線は Task6，青線は Task2，赤線は Task7 に対する評価値と探索率を示す . 図 11 で, 上のグ ラフは評価値の遷移を示す . 上のグラフでは探索後の評 価值を 100 として正規化している . 図 11 で, 下のグラ フは探索率を示す .ここで各点の探索率は , パラメータ 探索の回数を, 探索終了時のパラメー夕探索回数で割つ たものである .下のグラフでは探索終了時のパラメータ 探索回数を 100 として正規化し，各時刻での探索進行状 況を示した .なお図 12 , 図 13 の探索率も同樣に計算さ れる。

图 11 より, 新しいタスクが発生した時, 探索率が一旦 0 に落ちている.これは現在発生しているタスクが今ま でと違うタスクであると認識して記憶メモリを新しく作 り，探索を最初から実行していることを意味する．また 過去に経験したことのあるタスクが再び発生すると，前 回のタスク処理において探索した最適な評価値を用いて， 探索を再開している.つまり発生したタスクが，経験済 みのタスクであると認識して , 途中から探索を再開して いる．よって記憶メモリを作って経験を有効に利用でき ていることがわかる . 探索率が 100 になった時点で探索 が終了し，探索が終了したタスクが再び発生すると，探 索したパラメータを用いて高い評価值で行動を再開でき ている .このように記憶メモリを有効に使用することで，
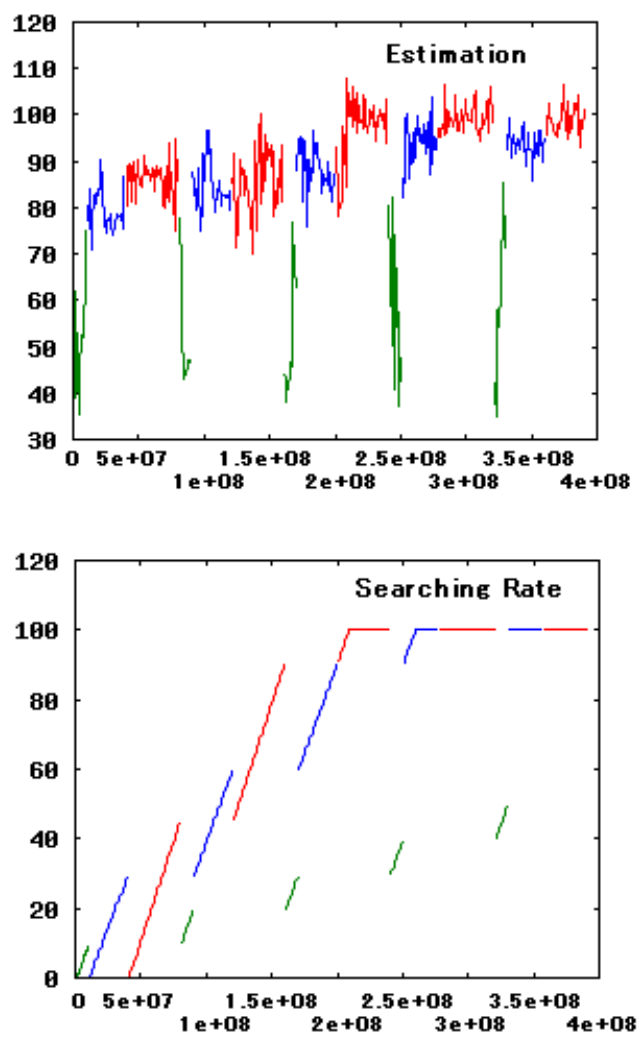

図 11 Task $6 \rightarrow$ Task $2 \rightarrow$ Task7 と变化させたときの評価値と探索 率の遷移 (横軸は動作経過時間 (単位: pas), 上 : 評価値の 遷移下：探索率の遷移，タスクが変化すると途中から探索 を再開している .)

タスクが変化する場合も探索を持続し, 変化する複数の タスクに柔軟に対応可能であることを示した .

\section{$5 \cdot 3$ ロボット 台数が変化する場合の探索}

この節では, パラメータ探索の最中やパラメータ探索 が終了した後に，ロボット間に通信トラブルなどが発生 する設定を仮定する．このような状況にも群ロボットが リーダロボットをタスク発生ごとに決定して行動し，破 綻することなく動き続けられるかどうかをシミュレーショ ンにより検証する．

\section{$\S 1$ 探索終了後にロボット台数が変化する場合}

まず Task1 を発生させた後に最適パラメータ状態の 探索 (ロボットの台数は 1 3 の範囲) を行う. 最適パラ メータ状態の探索終了後に 3 台のロボット (ロボット番号 $1,2,3)$ が通信不能となった状況を想定する .ここで通信 不能の状態とは, 他のロボッ卜と通信が不能となり群口 ボットとしての協調行動を行えない状態と定義する . 一 定時間が経過した後に，ロボット 1 台 (ロボット番号 2$)$ が復帰する (通信可能な状態となる) .

この実験では $(\alpha, \beta)=(0.0,1.0)$ とした .このシミュ レーション実験の結果を図 12 に示す.青線で示した地点 はロボットが故障した時間，緑線で示した地点はロボッ トが復帰した時間を示す .上のグラフか評価値の遷移で， 


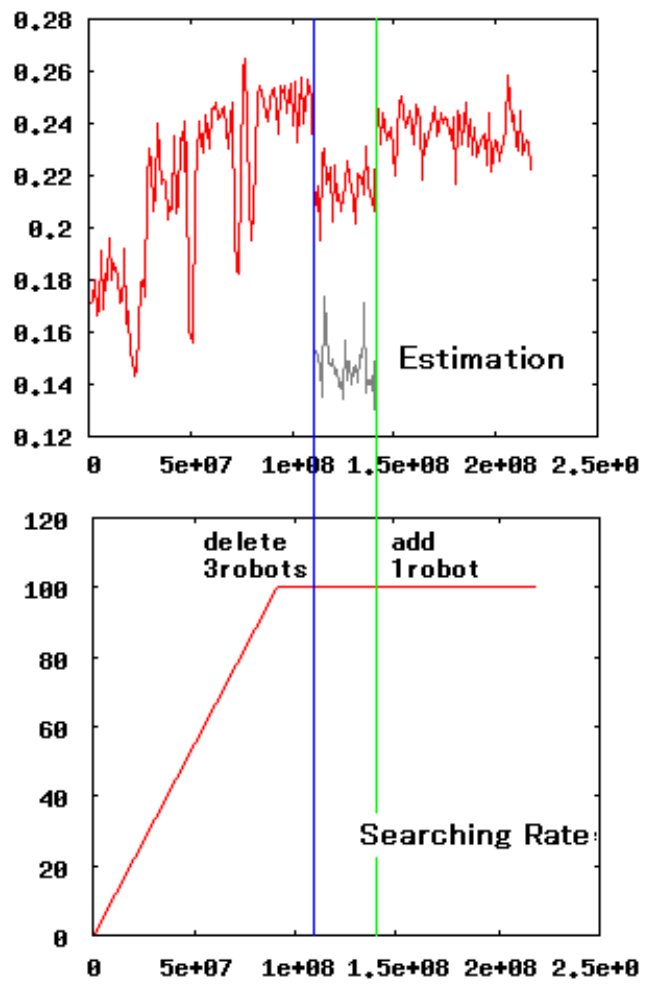

図 12 探索終了後にロボット台数を変化させたときの評価値と探 索率の遷移 (横軸は動作経過時間 (単位 : pas), 上 : 評価値 の遷移, 台数が減少しても光の台数で一番良い評価値を与 えるように行動している．下：探索率の遷移，探索が終了 すると 100 になり弚れ以上探索しない. )

下のグラフが探索終了時点の探索地点の数を 100 とした 探索率の遷移である。

この実験の場合，パラメータ探索が既に終了している のでロボット台数が減少しても探索率は変わらず 100 の ままである . まず正常に機能する 2 台のロボットは $4 \cdot 5 \cdot 6$ 節の方法で通信を行う際に, 3 台のロボットから応答がな いことを検知する .この後 , この 2 台のロボットはリーダ ロボットを選出し, 選出されたリーダロボットは記憶メ モリから探索状況を参照する. 結果としてこの 2 台の口 ボットは, 採りえる一番良いパラメータ状態で行動する。

ここでTask1の場合，タスク処理に必要なロボット台 数は 1 台 (表 1 より)なので, 作業フィールドに出るロ ボット台数の探索範囲は 1 台から 3 台である.これより 群ロボットは, ロボットが 2 台に減少すると探索範囲 1 台, 2 台の中で一番良い評価値を与えるパラメータ状態 を用いて行動することになる .この結果，群ロボットは 作業フィールドに出るロボット台数が 2 台以下の状況下 において，最大の評価値を得るパラメータ状態のまま行 動を行っている.しかし全体の台数が少ない分，5台存 在しているときに比へて評価値が悪化している (図 12 の 青線と緑線の間の部分) .これはエネルギーの補給などを 行っているとき，タスクの処理を交代可能なロボットが いないため, 常に作業フィールドに出るロボット台数を
一定に保てないためだと考えられる .

次に，この 2 台のロボットの行動がどの程度妥当かで あるかを検証する こここでは比較として, 2 台のロボット に記憶メモリを参照させず, ランダムなパラメータでタ スクを行わせる.ランダムなパラメータでロボットが行 動したときの評価值を図 12 中の灰色線に示す .この評価 値 (灰色線) と, 記憶メモリを参照した場合の評価值 (赤 色線)を比べると，記憶メモリを参照した場合の評価値 (赤色線) は良好である . これよりロボットの台数が減つ た状況下でも，探索経過を記憶メモリから参照すること で群ロボットは効率的にタスク処理を行っていることが わかる

次に一定時間後に, 1 台のロボットとの通信が復帰す る.ここでロボット台数が 3 台に増えた場合 (図 12 の緑 線以降の部分) でも記憶メモリを参照して探索状況を読 み出し, 光の台数で一番よい評価值を与えるパラメータ 状態で行動する . ロボット台数が 3 台になると評価は改 善され，ほぼ前回の評価を取り戻すことが可能となる． $\S 2$ 探索中にロボット台数が変化する

ここでは同じくTask1 を発生させた後に，探索の途中 で 3 台のロボット (ロボット番号 $1,2,3$ ) が通信不能となっ た (故障した) 状況を想定する。一定時間が経過した後に， ロボット 1 台 (ロボット番号 2 ) との通信が復帰する .こ の実験でも $(\alpha, \beta)=(0.0,1.0)$ とした .この結果を図 13 に示す.青線で示した地点はロボットか做障した時間 , 緑 線で示した地点はロボットが復帰した時間である .上の グラフか評価の遷移で, 下のグラフが探索終了時点の探 索地点の数を 100 とした探索率の遷移である.

作業フィールドに出るロボット台数が 2 台の探索範囲 をパラメータ探索する最中にロボットの台数が 2 台に減 少したため, 探索率のグラフからしばらくは探索が進む ことが読み取れる．しかし，作業フィールドに出るロボッ 卜台数が 3 台の探索範囲にはロボット台数が足りないた めに移れないので, 探索が一時中断し, 探索率はしばら く一定値になる . ロボットの行動は乥れまでの探索範囲 内で一番良い評価值を得るパラメータ状態で行動をする．

復帰した 1 台のロボットが追加されてロボット台数が 3 台になると，作業フィールドに出るロボット台数の探索 範囲を 3 台に移し探索を再開する，以上より，探索途中 でロボットの数が減少した場合でも, 兴の探索時点で得 られた行動則により作業を続けることが可能である．ま た新しいロボットが復帰すると, 探索を再開し最適なパ ラメータ状態 (行動則) を獲得することが可能であること を示した 。

\section{6. 考 察}

本章では，まず提案メカニズムの特性について考察す る. 次に 5 章のシミュレーション実験の結果を踏まえた 上で実験結果についての考察，実験結果から得られた知 


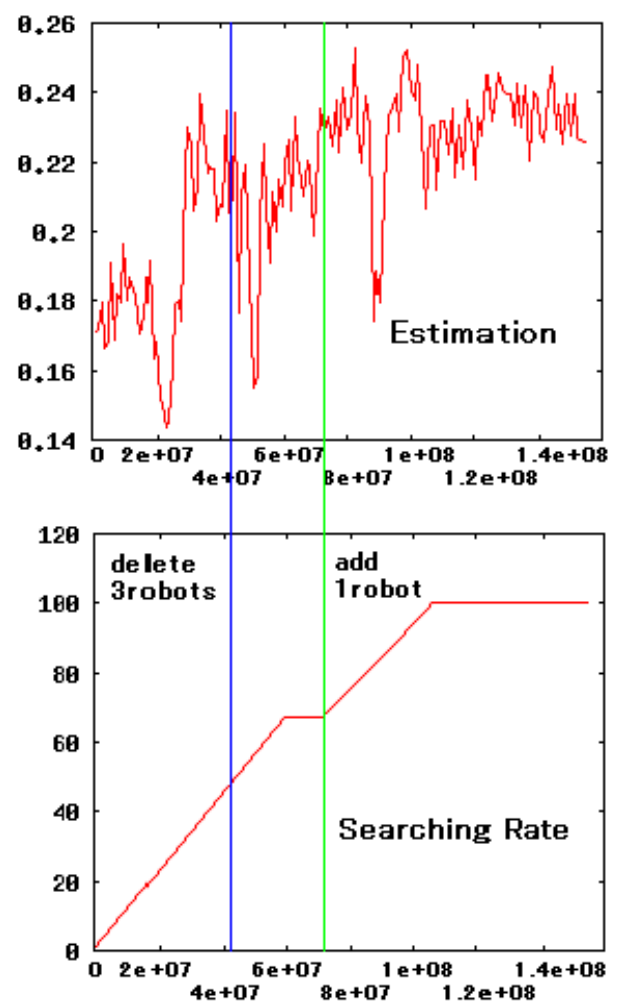

図 13 探索中にロボット台数を変化させたときの評価と探索率の 遷移 (横軸は動作経過時間 (単位：pas)，上：評価の遷移 下 : 探索率の遷移，探索が途中で中断されまた再開する)

見を述べる．最後に，実ロボットを用いた実装にむけて の問題点について考察する.

\section{$6 \cdot 1$ 提案メカニズムに関する考察}

本研究では, メカニズムの基盤に包摂アーキテクチャ を用い, 包摂アーキテクチャにパラメータ探索機能と記 憶メモリ生成機能を追加した．まず包摂アーキテクチャ のレベル 0 に障害物回避および徘徊の行動を設定し，レ ベル 1 にはエネルギー補給 (充電) を設定した .この $2 つ$ のレベルはロボットの最低限の行動を保障する .これに より通信の不具合などにより協調行動不可能となった口 ボットも，徘徊と充電を繰り返しながら通信の復旧を待 つといったことが可能である．またレベル 2 に充電場で の待機を設定し，レベル 3 にはタスクの処理に向かう行 動を設定した .レベル 4 にはロボットが適切な配置 (平衡 状態)に向かう行動を設定した . 総じてレベル $2,3,4$ は， 最低限の自律性を有する個々のロボットに群ロボットと しての協調性を持たせるために設定したと言うことが出 来る.

ここでリーダロボットが各ロボットの個人情報 (タスク 達成量およびエネルギ一残量)を用いて，適切なパラメー 多状態を探索した結果，レベル $2,3,4$ での各ロボットの行 動が決定される．まずレベル 2 では，タスクに向かうべ きロボットの台数と待機するロボットの台数が , この探 索結果から決定される .この台数に応じて各ロボットは，
タスクに近いロボットから順に乥の台数分だけタスクに 向かう（レベル 3). タスクに向かうロボットは，探索結 果から適切な配置 (位置) を計算した後に兴の場所に移動 し, タスク処理を行う (レベル 4).すなわち各ロボット はレベル 0,1 では自律的に行動し，レベル $2,3,4$ ではリー ダロボットの制御 (探索結果)にしたがって行動する .

本研究では, 学習 (探索) により各タスクに応じた群口 ボットの行動則を決定するために, リーダロボットを選 出し, 弚のロボットに学習を行わせる。一方で各ロボッ 卜は, タスク処理の他に状況に応じて障害物の回避やエ ネルギー補給をしなくてはならない．このような個々の ロボットの行動全てを,リーダロボットからのトップダ ウン的な指令で行うのは困難である. 弚こで本研究では 個々のロボットに最低限の自律性を持たせる (レベル 0,1$)$ ことで, この問題を回避した . 例えば, 各ロボットはエ ネルギーが咸った場合, タスク処理を止めてエネルギー 補給に戻ることを優先させる.この結果, ロボットがタ スク処理から離れ, 群ロボットとしての作業効率は低下 するものの，長期的に見れば群ロボット全体として破綻 しにくい行動選択を行っていると考えられる.

総じて提案メカニズムは, リーダ参照型の利点である 制御の安定性と群ロボットとしての柔軟性を兼ね備えて いると考えられる .

\section{$6 \cdot 2$ 実験結果についての考察と 知見}

\section{$\S 1$ 実験 $5 \cdot 1$ 節についての考察}

実験 $5 \cdot 1$ 節では, 各種の Task に対して適切なパラメー タを探索できるかどうかを検証した .この実験の結果 ,パ ラメータ探索後の評価値の向上 (図 5 , 図 6) および, 探 索後の群ロボットの適切な挙動 (図 7〜図 10) が確認され た .これらの結果より提案メカニズムで用いたパラメー 夕最適化手法の妥当性が示された .

\section{$\S 2$ 実験 $\mathbf{5} \cdot 2$ 節についての考察}

実験 $5 \cdot 2$ 節では, 複数のタスクが順々に発生する状況 下でも適切なパラメータを探索できるかどうかを検証し た .この実験結果から提案メカニズムでは, タスクの変 化を認識した後に, 記憶メモリに蓄積した学習結果を活 用し，速やかに効率的なタスク処理を行えることが示さ れた。

\section{$\S 3$ 実験 $\mathbf{5} \cdot \mathbf{3}$ 節についての考察}

実験 $5 \cdot 3$ 節では, パラメータ探索の直後 (実験 $5 \cdot 3 \cdot 1$ 節) および途中 (実験 $5 \cdot 3 \cdot 2$ 節) にロボットが通信不能に なるという設定下で実験を行った . 実験 $5 \cdot 3 \cdot 1$ 節の実験 結果 (図 12) から, 探索後に 3 台のロボットが通信不能 となった場合にも，記憶メモリに蓄積された学習結果を 活用することで, 比較的高い評価値を保ったままタスク 処理を続行可能であることが示された .ここで記憶メモ リの生成を行わなかった場合を想定して, 残り 2 台の口 ボットがランダムに行動した場合のシミュレーション実 験を行った .この結果からランダムに行動したロボット 
の，行動に対する評価值が非常に低いことがわかった (図 12 上の灰線部分) . したがってこの実験 $5 \cdot 3 \cdot 1$ 節の比較結 果から，蓄積した記憶メモリを活用した結果として，任 意のロボットが通信不能となった場合にも速やかに適切 な行動をとれることが示された . また実験 $5 \cdot 3 \cdot 2$ 節の結 果からも実験 $5 \cdot 3 \cdot 1$ 節の結果と同樣に, 記憶メモリの活 用による作業効率の改善がみられた .

総じて, シミュレーション実験 $5 \cdot 2$ 節, $5 \cdot 3$ 節の結果 から, タスク処理の経験 (パラメータ探索結果) をメモリ に蓄積し光れを必要に応じて活用することで, 提案する 群ロボットは作業環境の変化にも適応可能であることが 示された 。

通信不能となったロボットについて

$5 \cdot 3 \cdot 1$ 節, $5 \cdot 3 \cdot 2$ 節の実験では 3 台のロボットが通信不 能となったと仮定した .この通信不能となったロボット は，協調的なタスク処理には参加できないまでも，包捸 アーキテクチャ(レベル 0, レベル 1$)$ にしたがって単独で 徘徊する .この結果として , $5 \cdot 3 \cdot 1$ 節, $5 \cdot 3 \cdot 2$ 節の実験で 想定したように, ロボット間の通信が復帰することが期 待出来る。

復帰したロボットについて

次に $5 \cdot 3 \cdot 1$ 節, $5 \cdot 3 \cdot 2$ 節の実験では, 3 台のロボットが 通信不能となった後に 1 台のロボットが復帰する状況を 想定した .すなわち通信不可であったロボットが作業の 途中に通信が可能な状態，つまり協調行動に参加可能な 状態に復帰した場合を想定している．提案メカニズムで は記憶メモリを生成することで, 探索結果 (経験) を蓄積 し，これを活用することで速やかにロボット台数の変化 に適応可能である .この機能を利用することで, ロボッ 卜が作業中に復帰した場合，容易にこのロボットを協調 行動に参加させることが可能となった . また単にロボッ 卜を参加させるだけでなく，協調行動としての作業効率 も改善することが可能であることを実験結果より示した (図 12, 図 13 の緑線以降).

総じて実験 $5 \cdot 3$ 節では, 何らかの理由によりロボット が通信不可となる状況, また产のロボットとの通信が復 帰する状況を設定した .シミュレーションの結果から，こ のような状況下でもパラメータ探索を続行し, 群ロボッ 卜としての協調行動を破綻することなく行うことが可能 であることが示された .

\section{$6 \cdot 3$ 実装にむけての問題点}

本節では提案メカニズムを実ロボットに搭載する上で の問題点, 限界, 適用可能な実問題 (タスク)について考 察する .

まず第一に実ロボット同士が通信を行う場合，同期環 境ではなく非同期環境を想定しなくてはならない，非同 期環境では同期環境と異なり，通信のタイムラグを考慮 する必要がある．乥こで深刻な通信のタイムラグが発生 した場合を想定する．まず提案メカニズムではタスクの
発見後, リーダロボットを選出し，各ロボットは包摂アー キテクチャ上のレベル 0 からレベル 4 のどれかに移行す る.ここで何台かのタスク処理ロボットが，レベル 4 で

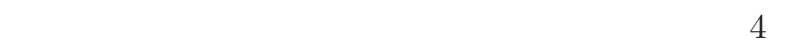
平衡状態に達するまでの時間を「処理開始期間」と定義 する.つまりタスクの発見から，レベル 4 の平衡状態に 達するまでの間に別のタスクが発生した，またはタスク が何らかの理由で消失した場合には提案する群ロボット は破綻する．逆に言うと深刻な通信によるタイムラグが 発生したとしても, タスクが変化および消失する前にレ ベル 4 に到達できれば群ロボットとしての機能が破綻す ることはない .なぜなら提案メカニズムではロボットの 基本的な行動の制御に包摂アーキテクチャを用いており 個々のロボットはいかなる場合にも原則として行動およ び作業を続けることが可能であるからである .

総じて，実ロボットを用いて非同期環境で実験を行う 場合には, 通信の問題 (タイムラグ) などが起きてロボッ 卜同士の情報共有が遅れると考えられる.このような状 況下でも提案メカニズムを搭載した群ロボットでは, パ ラメータ探索効率やタスク処理効率が低下する可能性は あるが，原則として破綻することなく動作を続けること ができると考えられる .

第二に非同期環境の上 , 何台かのロボットが通信不可 となった場合を想定する . 提案メカニズムでは, 通信が 不可となったロボットは協調行動を行うことは出来ない ただし徘徊 (包摂アーキテクチャ:レベル 0) と充電 (包摂 アーキテクチャ: レベル 1) を繰り返しながら, 通信の復 帰を待つことが可能である．またこれに並行して，通信 可能なロボットは提案メカニズムにしたがい, 群ロボッ トとしての協調行動を行うことも可能である . 具体的に は $4 \cdot 5 \cdot 6$ 節で述べた通信方法を用いて，リーダロボット が通信可能なロボットの台数を数え, 兴のロボットの台 数でタスクに対するパラメータ探索を行いながらタスク 処理を行う.

第三に非同期環境の上 , 全ロボットがタスクの発生を 認識不可能な場合を想定する.この場合には，タスク処 理を行うことは不可能となる．しかし最低一台のロボッ トがタスクの発生を把握できた場合には, タスクの発生 位置を通信可能なロボットに伝播させることで, 弚のタ スクの処理を行うことが可能となる .

以上の三項目をまとめて , 提案メカニズムを実ロボッ 卜に搭載した場合に，提案メカニズムの機能を保持でき， かつ協調行動可能な最低条件を以下に挙げる．

(1) 最低 1 台のロボットはタスクを発見可能

(2) 最低 2 台のロボットが存在する

(3)「処理開始期間」が，タスクか変化もしくは消失す るまでの期間より長くなる程の, 深刻な通信のタイ ムラグが発生しない 


\section{7. ま と め}

本研究では包摂アーキテクチャに独自のパラメータ探 索および記憶メモリの生成機能を加えることで，樣々な 種類のタスクやロボット台数が変化する状況においても ロボットが破綻することなく動き続け，パラメータ探索 により行動か改善される群ロボットメカニズムを提案し た。また計算や行動の決定を行うリーダロボットをタス ク処理ごとに決定することで, いつどのロボットが故障 (通信不能)したり復帰しても対応でき,リーダロボット により作業フィールドに出るロボット台数，平衡状態の パラメータがタスクに応じて適切に探索され，ロボット のタスクに対する行動か改善される．またリーダロボッ トによりタスクの認識, 記憶メモリの生成が行われるこ とにより, タスクの変化にも柔軟に対応可能である

これらのアルゴリズムの有用性を示すためにシミュレー ション実験を行った . 実験の結果，樣々なタスクに対し て適切な行動の探索が可能であることを示した . またタ スクか変化する状況やロボットが故障 (通信不能)する状 況，さらにはロボットの通信が復帰する状況にも，提案 する群ロボットは協調行動を続けることが可能であるこ とを検証した．今後，提案メカニズムを用いた実ロボッ 卜による実験を目指す．

\section{謝辞}

本研究の実施にあたり NEDO 産業技術研究助成事業 から支援を頂きました . 記して感謝いたします．

\section{$\diamond$ 参 考 文 献 $\diamond$}

[Balch 98] T. Balch and R.C. Arkin: Behavior-based Formation Control for Multirobot Teams, IEEE Transactions on Robotics and Automation, Vol.14, No.6, pp.926-939 (1998)

[Brooks 86] R.A.Brooks : A Robust Layered Control System for a Moble Robot, IEEE Journal of Robotics and Automation, Vol. RA-2, No.1, pp.14-23 (1986)

[Desai 01] P.J. Desai, P.J. Ostrowski and V. Kumar: Modeling and Control of Formations of Nonholonomic Mobile Robots, IEEE Transactions on Robotics and Automation, Vol.17, No.6, pp.905-908 (2001)

[Fredslund 02] J. Fredslund and M.J. Mataric : A General Algorithm for Robot Formations Using Local Sensing and Minimal Comunication, IEEE Transactions on Robotics and Automation, Vol.18, No.5, pp.837- 846 (2002)

[Kobayashi 03] F. Kobayashi, N.Tomita and F.Kojima: Reformation of Mobile Robots Using Genetic Algorithm and Reinforcement Learning, SICE Annual Conference, Vol.3, pp.2902-2907 (2003)

[Kostiadis 99] K. Kostiadis and H. Hu : Reinforcement Learning and Co-operation in a Simulated Multi-agent System, IEEE/RSJ International Conference on Intelligent Robots and Systems, Vol.2, pp.972-977 (1999)

[Miki 06] T.Miki, T, Nakamura: An Effective Simple Shepherding Algorithm Suitable for Implementation to a Multimobile Robot System, International Conference on Innovative Computing, Information and Control,Vol3, pp.161-165 (2006)

[Reynolds 87] C.W. Reynolds : Flocks, Herds, and Schools: A Distributed Behavioral Model, In Computer Graphics
ACM SIGGRAPH Conference Proceedings, Vol.21, pp.2534 (1987)

[Zhong 03] B. Zhong, Q. Zhang and Y. Yang: Real Time Reactive Strategies Based on Potential Fields for Robot Soccer, IEEE International Conference on Robotics, Intelligent Systems and Signal Processing, Vol.2, pp.1052-1057 (2003)

[太田 01] 太田 順, 新井 民夫 : 群知能ロボットシステム, 日本 ロボット学会誌, Vol.20, No.5, pp.487-490 (2001)

[则谷 04] 则谷学, 鎌野琢也, 安野卓, 鈴木茂行, 原田 寛信, 小 倉 明香 : 捕獲問題における群移動ロボットの協調行動の実現, 電気学会論文誌 C, Vol.124, No.2, pp.502-508, (2004)

[谷川 05] 谷川 裕海, 菅原 研, 小菅 一弘 : 簡単な力学特性に 基づく群ロボットの集団行動, 計測自動制御学会東北支部, 第 226 回研究集会, 資料番号 226- 5, (2005)

[牧野 04] 牧野 浩二, 松尾 芳樹: 個体への単純な仮想作用力 による自律移動ロボットの群挙動の制御, 日本ロボット学会誌, Vol.22, No.8, pp.1031-1042 (2004)

[宮田 00] 宮田なつき, 太田 順, 新井 民夫, 浅間 一: 群口 ボットによる異種作業割り付け型協調搬送, 電気学会論文誌 C, Vol.120, No.5, pp.634-640 (2000)

〔担当委員 : 山口 智浩〕

2006 年 9 月 28 日 受理

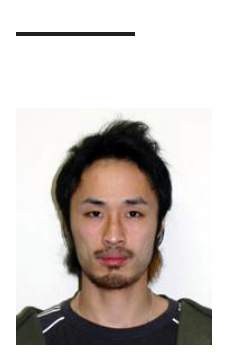

\section{紹 介}

\section{岡田 将吾}

2003 年横浜国立大学工学部知能物理工学科卒業，2005 年 東京工業大学大学院総合理工学研究科知能システム科 学専攻修士課程修了. 現在, 同大学博士課程在学中.

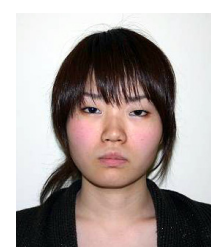

伊藤 芳子

2003 年大阪大学工学部機械工学科卒業, 2005 年 東京工 業大学大学院総合理工学研究科知能システム科学専攻修士 課程修了.現在，富士通（株）勤務。

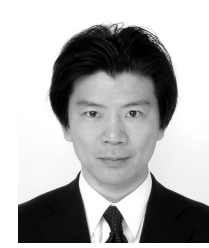

\section{長谷川 修(正会員)}

1993 年東京大学大学院電子工学専攻博士課程修了, 博士 (工学), 同年電子技術総合研究所入所, 1999 年から 1 年 間米国カーネギーメロン大学客員研究員, 2001 年産業技 術総合研究所主任研究員, 2002 年 東京工業大学像情報工 学研究施設助教授, JST さきがけ研究 21 研究者 (兼任) 。 